\title{
History of smoking cessation treatment in Poland - the strengthening role of cytisine as the most effective and safe pharmacotherapy
}

\author{
Witold A. Zatoński ${ }^{1,2}$, Kinga Janik-Koncewicz',2, Zuzanna Stępnicka ${ }^{3}$, Katarzyna Połtyn-Zaradna ${ }^{3}$ \\ Katarzyna Zatońska ${ }^{3}$, Aleksandra Herbeć ${ }^{2,4}$ \\ 'Institute - European Observatory of Health Inequalities, Calisia University, Kalisz, Poland \\ ${ }^{2}$ Health Promotion Foundation, Nadarzyn, Poland \\ ${ }^{3}$ Department of Social Medicine, Wroclaw Medical University, Poland \\ ${ }^{4}$ University College London, United Kingdom
}

\begin{abstract}
One of the greatest public health successes in Poland since the 1990s has been a decline in tobacco-related morbidity and mortality, including from lung cancer and cardiovascular disease. The steady decline in smoking cigarettes among adults in Poland during this period was among the most important factors contributing to this success. The key enabling factor in this process was the increasing range and availability of different pharmacotherapy supporting smoking cessation, including nicotine replacement therapy, but especially of the safe and affordable cytisine. The popularity of cytisine has been continuously growing among smokers in Poland. New developments in cytisine-based treatments and research in Poland and abroad can further strengthen global tobacco control efforts. Cytisine requires much greater interest from the medical community and from those responsible for public health in Poland.
\end{abstract}

KEY WORDS: smoking cessation, cytisine, varenicline, nicotine replacement therapy, Poland.

ADDRESS FOR CORRESPONDENCE: Witold A. Zatoński, Institute - European Observatory of Health Inequalities, Calisia University, Nowy Świat 4, 62-800 Kalisz, Poland, e-mail: w.zatonski@akademiakaliska.edu.pl

\section{INTRODUCTION}

At the end of 1980s, Poland was a country with one of the highest levels of tobacco consumption as well as one of the highest rates of the prevalence of the smoking-related diseases in the world [1-6]. The public health actions that started at the beginning of the socio-economic transformation period in the early 1990s included a strategic national programme to reduce the health effects of tobacco consumption, as well as the adoption of the Parliamentary Act in 1995 [4, 7-11], led to a significant reduction in tobacco consumption and smoking frequency $[4,8]$. Tobacco sales fell from about 100 billion cigarettes in the early 1990s to less than 40 billion in 2017 (Fig. 1) and prevalence of smoking declined from $73 \%$ in 1976 to $24 \%$ in 2019 in men, and from $30 \%$ in
1982 to $18 \%$ in 2019 in women $[1,12,13]$ resulting in a significant reduction in the incidence and mortality from tobacco related diseases $[1,3,14,15]$. Furthermore, according to the recent international publications, after 1990 Poland became one of the countries with the fastest decline in cigarette consumption as well as morbidity and mortality resulting from tobacco-related diseases (Figs. 1 and 2) [4, 6, 14-17]. A good illustration of this phenomenon is the decreasing trend in mortality from lung cancer in young and middle-aged male and female population (Fig. 2) and from cardiovascular diseases (Fig. 3). The lung cancer is a disease that almost solely occurs in smokers $[3,4]$, while adult cardiovascular diseases are said to be caused by cigarette smoking in about $30-50 \%$ cases in the European countries [18]. 
A

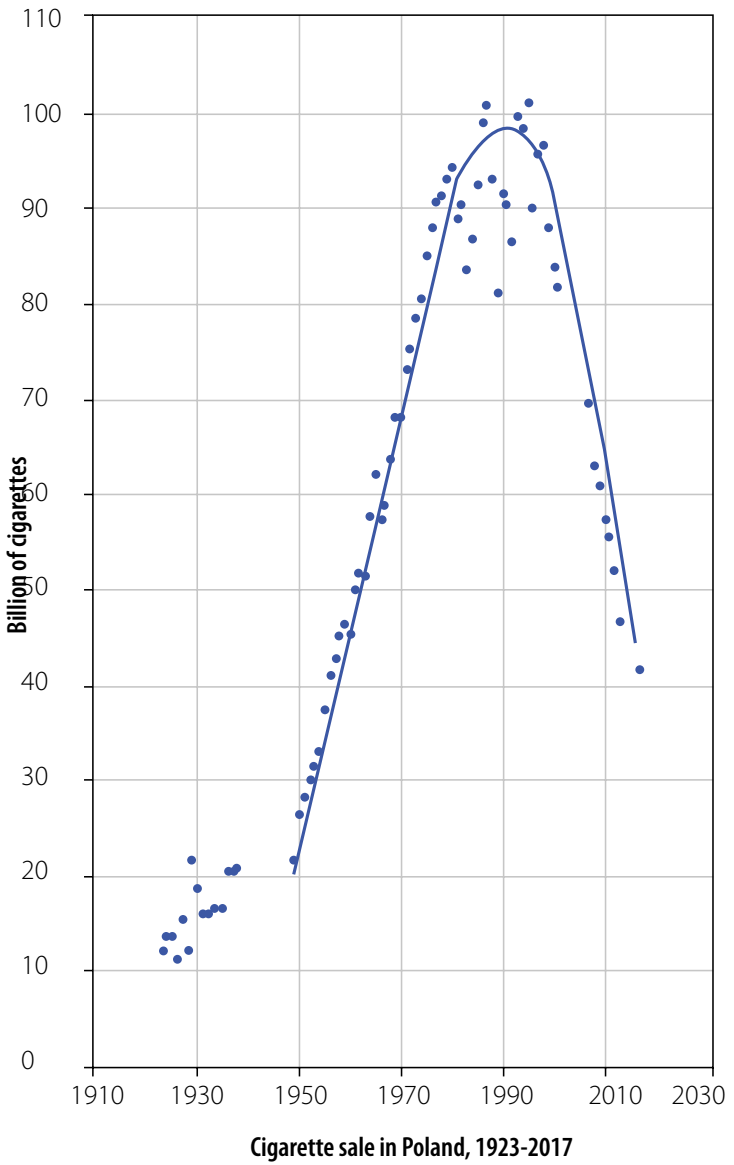

$\mathrm{B}$

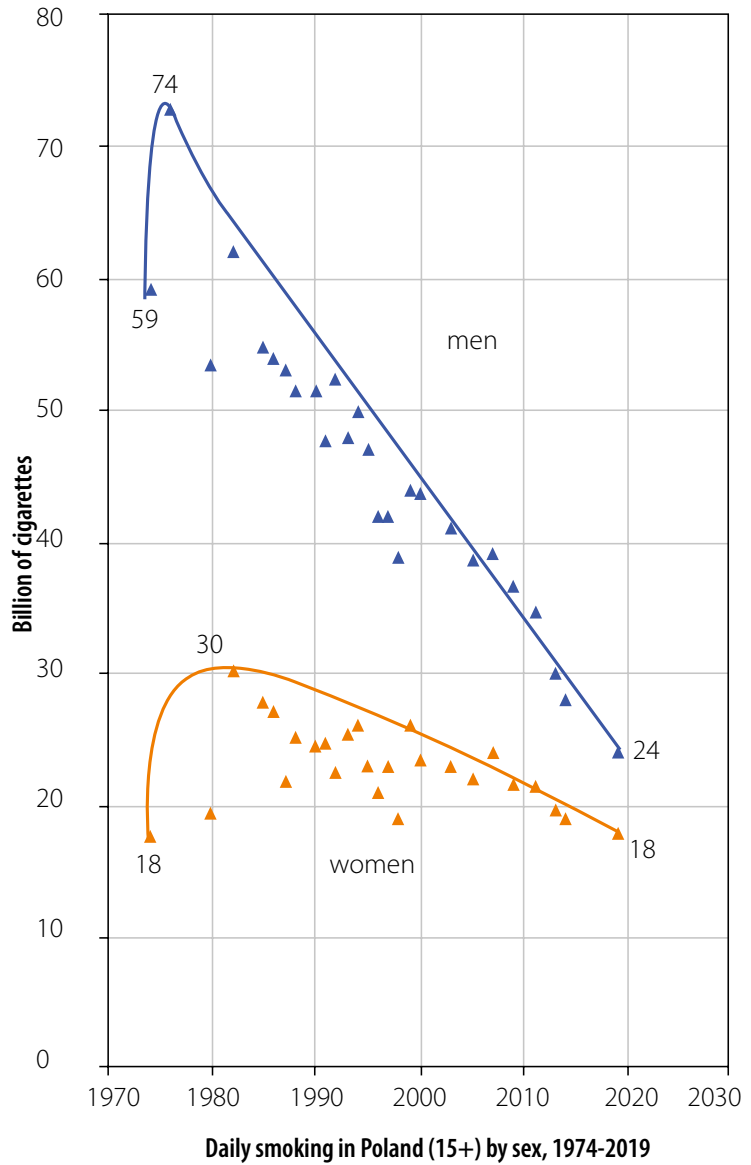

FIG. 1. Cigarette sale (A) and prevalence of daily smoking (B) in Poland $[1,12]$

\section{HISTORY OF SMOKING CESSATION TREATMENT IN POLAND}

Smoking cessation pharmacotherapy seems to be an important factor contributing to the decrease in the consumption of cigarettes in Poland, especially in the last decade.

The market for modern, science and evidence-based medicines to treat tobacco dependence has only been developing worldwide since the early 1980s [19-22]. In the recent decades in Europe there have been few drugs of scientifically proven effects sold on the market. Currently, their sale adds up to hundreds of millions of packages sold annually [19-22] and the market continues to grow. A commonly used and often available without a prescription primary treatment for quitting smoking, recommended by the World Health Organization (WHO) is nicotine replacement therapy (NRT). It works by replacing nicotine from cigarettes for chemically pure nicotine. This chemically pure nicotine is delivered in many forms, including as a gum, patches, lozenges, tablets, inhalers, nasal and mouth spray, and stripes. The first NRT treatment was produced in the form of a "chewing" gum and was sold under the trade name "Nicorette ${ }^{\infty}$. It was introduced to the market in the early 1980s by the Swedish pharmacological company "Leo" [23].

This group of substances used for tobacco dependence treatment has been introduced onto the Polish market already in 1980s, just a few years after their debut in Sweden. The fast-track introduction was made possible thanks to the pressure of Polish oncologists and NRT was first sold in so called Pewex chain shops where items could be purchases only using hard currency, primary USD. Thanks to this, NRT has quickly gained prestige and popularity among smokers in Poland. Sales of all types of NRT have increased in Poland from about half a million of packages per year at the beginning of 2000 to over 3 million in 2019 [24].

In the 1990s, another class of smoking cessation drugs that interact with receptors in the brain were developed. Bupropion was introduced to the market first (sold under the name ZybanTM), followed by varenicline (sold under the name Champix ${ }^{\circledast}$ in the European Union (EU) and Chantix ${ }^{\circ}$ in the USA). Varenicline was synthetically manufactured in the 1990s by Pfizer, but its natural counterpart - cytisine - on which the varenicline's chemical and biological properties were modelled, 

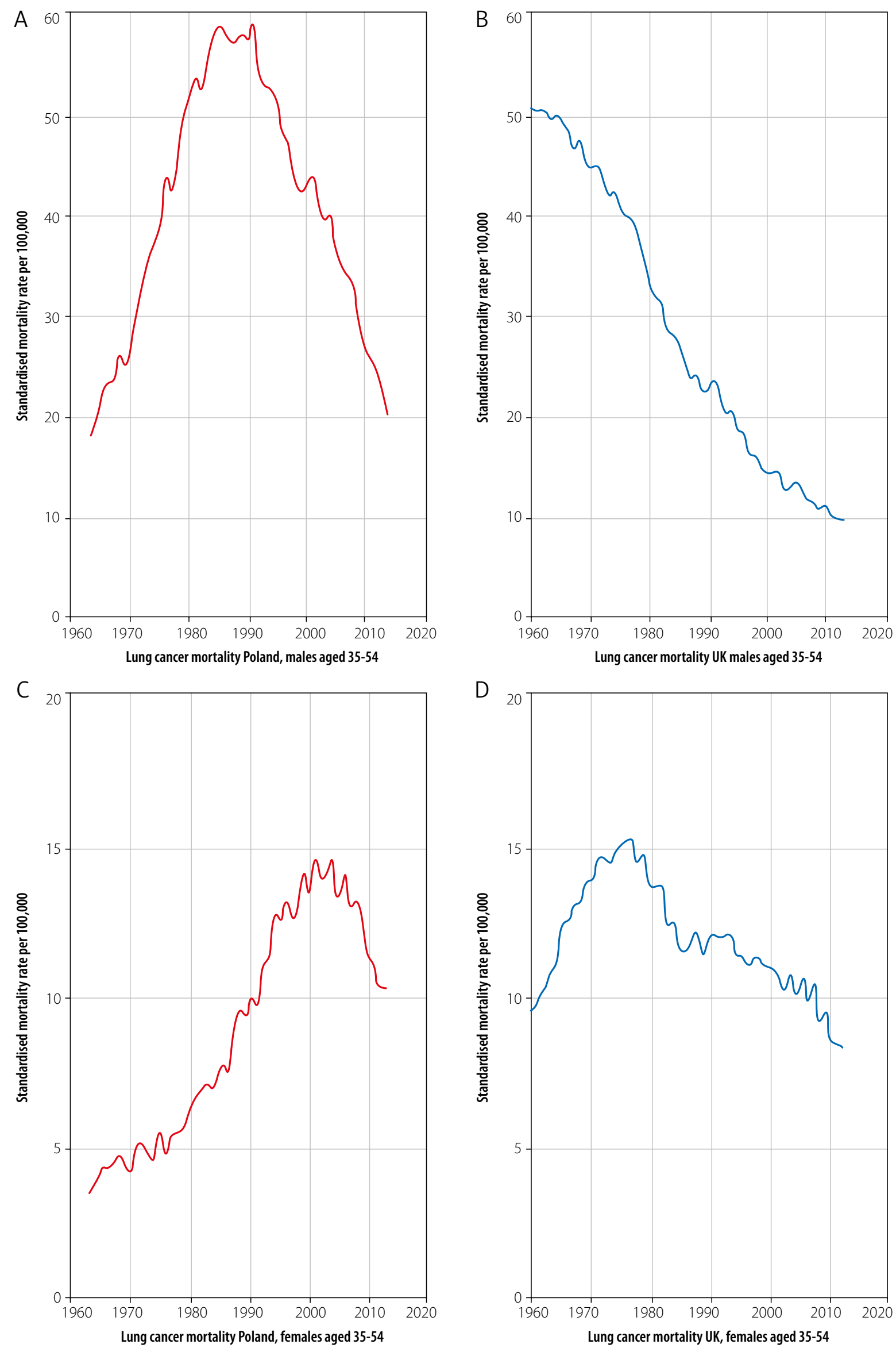

FIG. 2. Lung cancer mortality, age group 35-54, males and females, Poland vs UK [2, 3] 

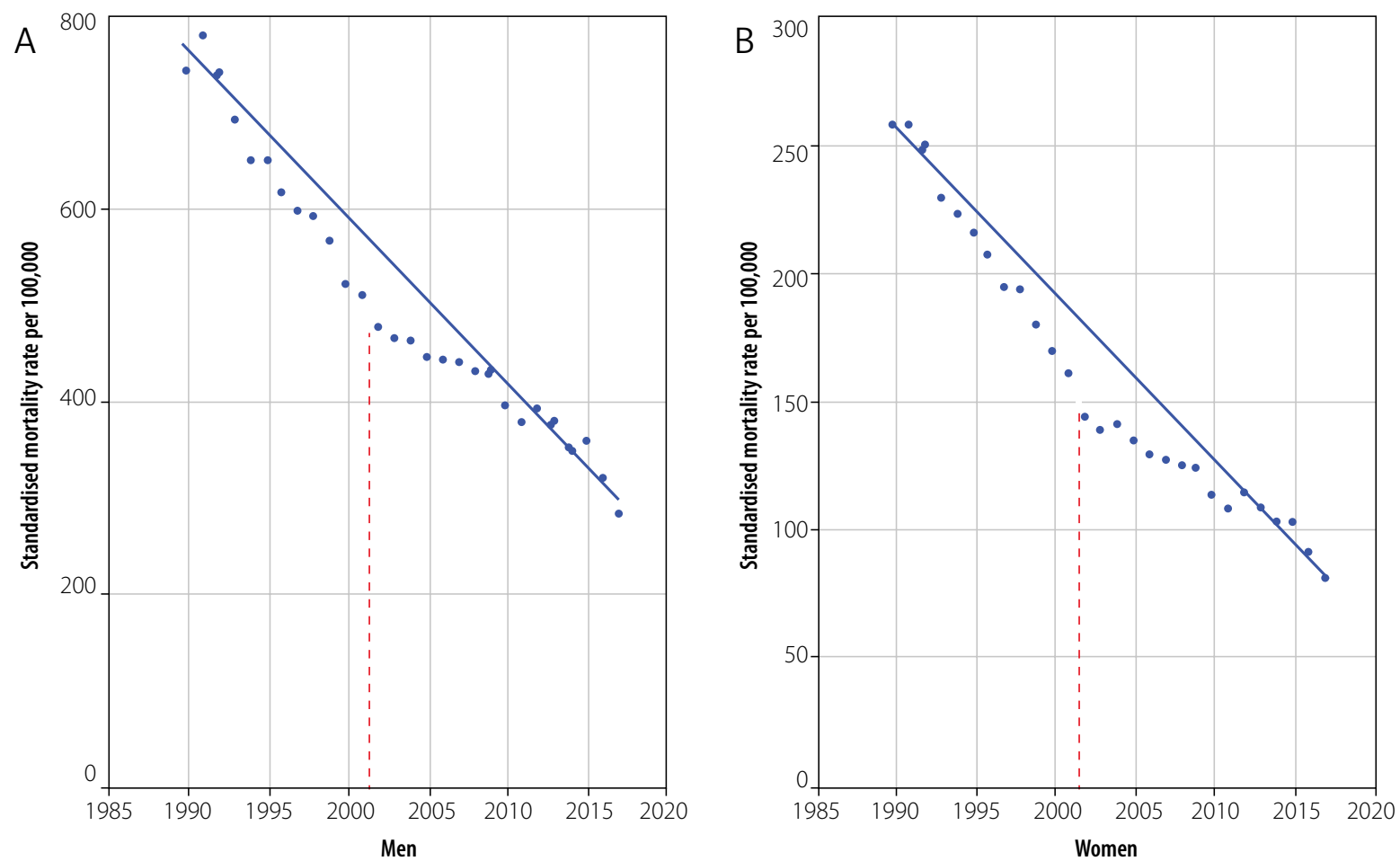

FIG. 3. Time trend of mortality due to cardiovascular diseases (CVD) in age group 45-64 years, Poland (source:WHO Mortality Database; mortality rates standardised per world standard population)

has been present in the countries of Easter Europe since 1960s already [25-27]. Cytisine and varenicline belong to the same group of partial agonist and a partial antagonists of nicotine receptors $[25,27]$. Both substances have a high affinity for the $\alpha_{4} \beta_{2}$ nicotinic receptors. As cytisine, varenicline block nicotine receptors in brain and keep them prevent from binding with nicotine. Pharmacological impacts of cytisine and varenicline administration are a reduction of satisfaction with smoking and a decline of nicotine craving, which occurs after a period of abstinence from tobacco [20,28-36]. In most countries of the world, including the US and all western EU countries, varenicline became a very popular smoking cession treatment, together with the NRT [19-22]. Varenicline is considered the most effective smoking cessation treatment in Western countries, especially in comparison to NRT and when combined with behavioural support $[37,38]$. However, varenicline has been available only on prescription with the cost of the therapy very high in countries with no or limited reimbursement for smoking cessation therapy. Moreover, although safe [39], varenicline use is nonetheless associated with some side effects. For all these reasons, there has been a long-standing discussion among smoking cessation experts on the similarities and differences between cytisine and varenicline and the benefits of using cytisine [40, 41].

The Polish market for the treatment of smoking addiction is very different from that of the western countries. The main difference between Poland and the other western countries is the availability and sale, on a population scale, of a plant-based drug called cytisine. While in 2019 there were 6.8 million of smokers in Poland [13], the annual sale of cytisine alone reaches hundreds of thousands of packages. This drug was developed over half a century ago by two visionary Bulgarian scientists, XD Paskov and VK Dobrev in Bulgaria [42-47] and it was in use for several decades in many eastern European countries that were under the Soviet Bloc rule, but on a very small scale $[20,29,30,40,48-54]$.

Cytisine is a plant-based alkaloid. It is obtained from the extract from the Laburnum anagyroides tree, commonly called "false tobacco" or "golden rain" found in central and southern Europe, as well as from the Kowhai tree native to New Zealand. Cytisine has a chemical structure and receptor binding mechanism similar to that of nicotine. It is a partial agonist of $\alpha_{4} \beta_{2}$-cholinergic nicotine receptors in the brain. Being the agonist, it acts like nicotine and stimulates dopaminergic neurons whilst on the other hand blocking nicotine receptors in brain and keep them prevent from binding with nicotine. This effect is weaker than in the case of nicotine delivered from cigarette smoke, the release of dopamine is slower and less intense. However, the release of dopamine relieves the syndrome of nicotine withdrawal [27, 35, 36, 55-57].

Cytisine has been present on the Polish pharmacological market since the 1970s, but initially it was rarely used [58, 59]. Its sale before 2000 was about $20-40$ thousand packages per year (Figs. 4 and 5). However, after the 


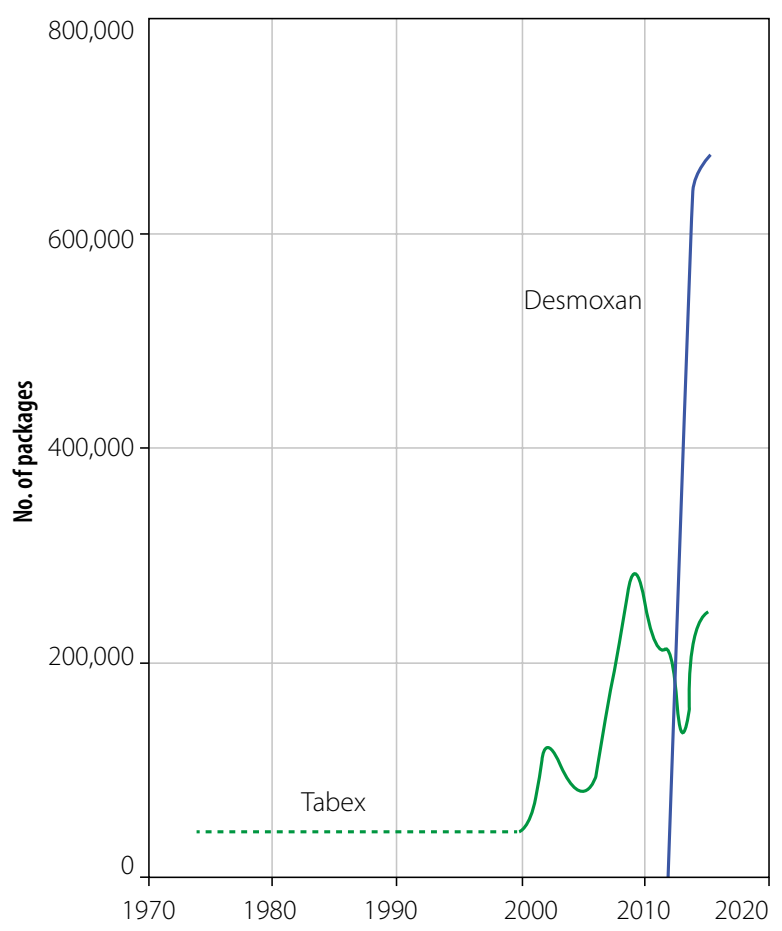

FIG. 4. Cytisine sale (Tabex and Desmoxan) in Poland until 2015 [19, 53]; prepared on the basis of data from IMS Health Poland

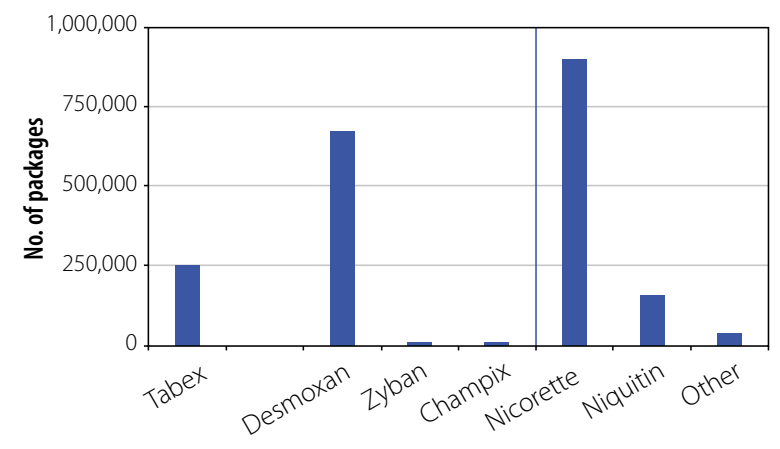

FIG. 5. Sale of smoking cessation drugs in Poland in 2015 [19]; prepared on the basis of data from IMS Health Poland

socio-economical changes and the preparation of Poland to join the EU in 2004, the pharmaceutical records of cytisine were questioned and considered to be insufficient for the registration of the drug in the EU. Under the pressure from the medical community in Poland, mostly cancer researchers, the Polish Ministry of Health had agreed to conditional registration of the drug under the condition of undertaking modern clinical trial assessing the efficacy and safety of cytisine [20]. For many years, Cancer Center in Warsaw became a centre of tobacco control activities in Poland and the Director of Epidemiology and Prevention Division was a co-chairman of the National Tobacco Control Commission by the Ministry of Health.
A research group from the Department of Epidemiology of the Cancer Centre in Warsaw under the leadership of the first author of this paper (WZ) has started an extensive research on cytisine. These studies were conducted in good cooperation with the producer of the drug (Sopharma, Sofia, Bulgaria), who made drugs available for research [28]. First, an open observational clinical trial into the safety and effectiveness of cytisine was conducted $[60,61]$. Then, in collaboration with a renowned group of researchers from the University College London, a double-blind placebo-controlled clinical trial, the so-called Tabex Smoking Cessation trial (TASK) was conducted. The principal investigators on the trial were Professor Witold Zatoński from the Cancer Centre in Warsaw and Professor Robert West from the University College London in the UK [62].

In 2011, the New England Journal of Medicine (NEJM), one of the most influential medical journals, published the results of this first randomised clinical trial of cytisine. The trial was conducted in accordance with the contemporary EU regulations for clinical trials, and have showed that cytisine is almost 3.5 times more effective for smoking cessation than placebo, and is safe $[20,62]$. The report prepared for the Polish Ministry of Health by the first author of the publication (WZ) and his research team allowed for the unconditional registration of cytisine as a pharmacological drug in Poland. At the same time, cytisine was recognised to be sufficiently safe to be sold through pharmacies without a prescription. Consequently, in accordance with the Polish Anti-tobacco law from 1995, cytisine advertisement as a stop smoking medication was allowed in the media, including on the TV $[7,53]$.

Publication of clinical trials in NEJM, promotion of cytisine at numerous scientific congresses, success in the field of tobacco control in Poland [11, 63, 64], have all contributed to the beginning of wide interest in this cytisine drug in many countries around the world. This was the beginning of interest of Polish drug manufacturers in smoking cessation. It had led to the production of new cytisine-based treatments on the Polish market under the trade names Desmoxan and Recigar [53], next to the Tabex produced by Bulgaria.

\section{OTHER TOBACCO CONTROL ACTIVITIES IN POLAND}

At the same time, since the beginning of the 1990s, extensive public health and tobacco control activities have been initiated in Poland to create a national system to aid treatment of tobacco [20, 21, 60, 64]. JanikKoncewicz et al. [19] described the constituent factors of this system which, among others, led to the creation and promotion of the evidence-based principles for smoking cessation treatment, emergence of a consensus on the diagnosis and treatment of the tobacco dependence prepared by the most eminent Polish doctors [20-22], as 
well as the organisation of a broad training programme on smoking cessation for healthcare professionals [65].

As part of this work, the Health Promotion Foundation (HPF), a non-governmental organization created in 1992 with the main aim on championing tobacco control activities in Poland. Amongst others, HPF has organized a competition „Quit smoking together with us" and prepared set of publications on smoking cessation treatment, including a guide "How to quit smoking. Professor Witold Zatoński advises" published in 1.5 million copies. Thanks to all these activities, Poland has become one of the leaders in tobacco control worldwide $[63,66,67]$.

\section{RECENT DEVELOPMENTS ON CYTISINE}

The success of cytisine in Poland has contributed to a growing interest in this drug abroad. Professor Natalie Walker and her team at University of Auckland in New Zealand have been among a few research groups who have been recently intensely researching the effectiveness and safety of cytisine in New Zealand. The first trial conducted by her team compared cytisine with NRT (using a design similar to that of the TASK study), and provided evidence that when combined with brief behavioral stop smoking support, cytisine was superior to NRT in helping smokers quit smoking, and althought it was associated with a higher frequency of self-reported side-effect, it was nonetheless safe $[53,68,69]$.

Most recently, a state-private consortium Achive Life Sciences (https://achievelifesciences.com/) was established in the USA to develop and research a cytisine-based drug, called "cytisinicline". To date, Achive Life Sciences has carried out several clinical studies, some modelled on the TASK study, to determine the efficacy and safety of the drug via a programme called Ongoing Research on Cytisinicline for Addiction, or ORCA (http://orcaprogram. com/). A cytisine-based drug developed by Achive was used in a head-to-head comparative study of cytisine and varenicline (the RAURORA study), described below.

\section{THE RAUORA STUDY}

The first trial comparing cytisine with varenicline (the RAUORA study) was conducted by Professor Natalie Walker and her team [69]. The randomised double-blind trial recruited 679 patients who were randomised to receive cytisinicline or varenicline for 12 weeks. The end point of the study after 6 months is confirmed by biochemical tests for persistent nicotine abstinence. The preliminary findings from this clinical trial shows that the cytisine was more effective in quitting smoking than varenicline, as announced by Achieve Life Sciences in a report from 29 June 2020 [70]. Importantly, the study also showed that the cytisine drug showed significantly fewer side effects compared with varenicline.

The RAUROA study is now completed and awaiting publication in a peer-reviewed medical journal and should be published in the coming months. It is bringing further evidence that cytisine-based pharmacotherapy, which has been used in Poland on a population scale and very intensively since 2000 , is potentially the most effective and safe smoking cessation drug on the market. Moreover, the price of this generic is an order of magnitude smaller than that of varenicline.

It seems that the RAUORA study is another step in laying the foundations for the effective tobacco control worldwide. Cytisine is gradually becoming an "aspirin of tobacco control". It is very popular among smokers in Poland and is being sold in millions of packages per year. Thus, it requires much greater interest from the medical community and from those responsible for public health in Poland.

\section{CONCLUSIONS}

One of the greatest public health successes in Poland since the 1990s has been a decline in tobacco-related morbidity and mortality, including from lung cancer (found among $60-80 \%$ of smokers) and cardiovascular disease (30-50\% of smokers). Among the important, if not the most important factors contributing to this success have been a steady decline in smoking cigarettes among adults in Poland during this period. The availability of pharmacotherapy supporting smoking cessation, and especially of the safe and affordable cytisine-based treatment, was a key enabling factor. The popularity of cytisine has been continuously growing among smokers in Poland and remains at a high level. New developments in cytisine-based treatments and research in Poland and abroad can be further strengthen global tobacco control efforts. This warrants cytisine having much greater interest from the medical community and from those responsible for public health in Poland.

\section{ACKNOWLEDGEMENTS}

The authors of the paper would like to thank IMS Health (IQVIA) for providing data on sales of tobacco (nicotine) dependence treatment drugs in Poland.

\section{DISCLOSURE}

The authors report no conflict of interest.

\section{References}

1. Zatoński WA, Zatoński M, Janik-Koncewicz K, et al. Hundred years of cigarette smoking in Poland: three phases of the tobacco epidemic. J Health Inequal 2017; 3 (2): 118-122.

2. Zatoński WA, Tukiendorf A, Zatoński M, et al. Lung cancer mortality decline among middle-aged men and women in Poland and the UK. J Health Inequal 2017; 3 (2): 123-126.

3. Zatoński WA, Zatoński M. Poland's rapid lung cancer decline in the years 1990-2016. The first step towards the eradication of lung cancer in Poland. Health Prob Civil 2017; 11: 211-225.

4. Zatoński $\mathrm{W}$ and HEM project team. Closing the health gap in European Union. The Maria Skłodowska-Curie Memorial Cancer Center and Institute of Oncology, Warsaw 2008. 
5. Zatoński W, Przewoźniak K, Sulkowska U, et al. Tobacco smoking in countries of the European Union. Ann Agric Environ Med 2012; 19: 181-192.

6. Zatoński WA, Bhala N. Changing trends of diseases in Eastern Europe: closing the gap. Public Health 2012; 126: 248-252.

7. Ustawa z dnia 9 listopada 1995 r. o ochronie zdrowia przed następstwami używania tytoniu i wyrobów tytoniowych (Dz. U. $1996 \mathrm{nr}$ 10, poz. 55) [Journal of Laws of the Republic of Poland 1996, nr 10, poz. 55. Law from 9 November 1995 regarding the protection of health from the consequences of using tobacco and tobacco products].

8. Zatoński MZ. State, society, and the politics of smoking in Poland, during and after communism (1960-2000). PhD thesis. London School of Hygiene \& Tropical Medicine, London 2019.

9. Boyle P, Gray N, Henningfield J, et al. Tobacco Science, Policy and Public Health. Second edition. Oxford University Press, Oxford 2010.

10. Zatoński WA. The Polish Anti-tobacco Law-20 years on. J Health Inequal 2016; 2 (1): 25

11. Zatoński M, Zatoński WA, Przewoźniak K, Jaworski M. The sig nificance and impact of the Polish Anti-tobacco Law. J Health Inequal 2016; 2 (1): 32-35.

12. Pinkas J, Kaleta D, Zgliczyński WS, et al. The prevalence of tobacco and e-cigarette use in Poland: a 2019 nationwide cross-sectional survey. Int J Environ Res Public Health 2019; 16 (23): 4820 .

13. Janik-Koncewicz K, Zatoński W, Zatońska K, et al. Cigarette smoking in Poland in 2019: the continuing decline in smoking prevalence. J Health Inequal 2020: 6 (2): ...

14. Hoffman SJ, Mammone J, Rogers Van Katwyk S, et al. Cigarette consumption estimates for 71 countries from 1970 to 2015 systematic collection of comparable data to facilitate quasi-experimental evaluations of national and global tobacco control interventions. BMJ 2019; 19: I2231.

15. GBD 2015 Tobacco Collaborators. Smoking prevalence and attributable disease burden in 195 countries and territories, 1990-2015: a systematic analysis from the Global Burden of Disease Study 2015. Lancet 2017; 389: 1885-1906.

16. $\mathrm{Ng} \mathrm{M}$, Freeman MK, Fleming TD, et al. Smoking prevalence and cigarette consumption in 187 countries, 1980-2012. JAMA 2014; 311: 183-192.

17. World Health Organization. WHO global report on trends in prevalence of tobacco use 2000-2025. Third edition. Available from: https://www.who.int/publications/i/item/who-global-report-on-trends-in-prevalence-of-tobacco-use-2000-2025-thirdedition (accessed: 5 November 2020).

18. Unal B, Critchley JA, Capewell S. Explaining the decline in coronary heart disease mortality in England and Wales between 1981 and 2000. Circulation 2004; 109 (9): 1101-1107.

19. Janik-Koncewicz K, Zatoński M, Herbeć A, Zatoński WA. The role of the Health Promotion Foundation in building capacity to treat tobacco dependence in Poland: past, present and future. J Health Inequal 2017; 3 (2): 127-132.

20. Zatoński W, Górecka D, Opolski G, et al. Konsensus dotyczący rozpoznawania i leczenia zespołu uzależnienia od tytoniu
[Consensus on diagnosis and treatment of tobacco dependence]. Medycyna Praktyczna 2006; 7: 1-24.

21. Zatoński W, Jankowski P, Banasiak W, et al. Wspólne stanowisko dotyczące rozpoznawania i leczenia zespołu uzależnienia od tytoniu u pacjentów z chorobami układu sercowo-naczyniowego [Common position on the diagnosis and treatment of tobacco dependence syndrome in patients with cardiovascular diseases]. Kardiologia Polska 2011; 69 (1): 96-100.

22. Herbeć A, Janik-Koncewicz K, McEwen A, et al. Development and evaluation of STAR - an expert digital platform supporting training and delivery of cessation interventions by healthcare professionals in Poland - Project overview. J Health Inequal 2017; 3 (2): 133-137.

23. Zatoński WA, Zatoński M. Health in the Polish People's Republic. J Health Inequal 2016; 2 (1): 7-16.

24. Monitor Rynku Leków. Środki antynikotynowe [Drug market monitor. Anti-smoking measures]. OSOZ Polska 2020; 10: 69-74.

25. Coe JW, Brooks PR, Vetelino MG, et al. Varenicline: an $\alpha 4 \beta 2$ nicotinic receptor partial agonist for smoking cessation. J Med Chem 2005; 48(10): 3474-3477.

26. Rollema H, Shrikhande A, Ward KM, et al. Pre-clinical properties of the $\alpha 4 \beta 2$ nicotinic acetylcholine receptor partial agonists varenicline, cytisine and dianicline translate to clinical efficacy for nicotine dependence. Br J Pharmacol 2010; 160: 334-345.

27. LeSage MG, Shelley D, Ross JT, et al. Effects of the nicotinic receptor partial agonists varenicline and cytisine on the discriminative stimulus effects of nicotine in rats. Pharmacol Biochem Behavior 2009; 91 (3): 461-467.

28. Tutka P, Zatoński W. Cytyzyna. Właściwości farmakologiczne leku stosowanego w leczeniu zespołu uzależnienia od tytoniu [Cytisine. The pharmacological properties of a medicine used in treatment of tobacco dependence]. Medycyna Praktyczna Kraków, 2006

29. Tutka P, Zatoński W. Cytisine for the treatment of nicotine addiction: from a molecule to therapeutic efficacy. Pharmacol Rep 2006; 58: 777-798.

30. Prochaska JJ, Das S, Benowitz NL. Cytisine, the world's oldest smoking cessation aid. BMJ 2013; 347: f5198.

31. Aveyard P, West R. Cytisine and the failure to market and regulate for human health. Thorax 2013; 68(11): 989.

32. Stapleton JA. The case for licensing cytisine now for smoking cessation is overwhelming. BMJ 2013; 347: f5736.

33. Tutka P, Vinnikov D, Courtney RJ, Benowitz NL. Cytisine for nicotine addiction treatment: a review of pharmacology, therapeutics and an update of clinical trial evidence for smoking cessation. Addiction 2019; 114 (11): 1951-1969.

34. Slater YE, Houlihan LM, Maskell PD, et al. Halogenated cytisine derivatives as agonists at human neuronal nicotinic acetylcholine receptor subtypes. Neuropharmacology 2003; 44: 503-515.

35. Chandler CJ, Stolerman IP. Discriminative stimulus properties of the nicotinic agonist cytisine. Psychopharmacology (Berl) 1997; 129: 257-264.

36. Radchenko EV, Dravolina OA, Bespalov AY. Agonist and antagonist effects of cytisine in vivo. Neuropharmacology 2015; 95: 206-214 
37. Stead LF, Koilpillai P, Fanshawe TR, Lancaster T. Combined pharmacotherapy and behavioural interventions for smoking cessation. Cochrane Database Syst Rev 2016; 3: CD008286.

38. Aveyard P. The place of varenicline in smoking cessation treatment. Thorax 2008; 63 (8): 666-668.

39. Anthenelli RM, Benowitz NL, West R, et al. Neuropsychiatric safety and efficacy of varenicline, bupropion, and nicotine patch in smokers with and without psychiatric disorders (EAGLES): a double-blind, randomised, placebo-controlled clinical trial. Lancet 2016; 387 (10037): 2507-2520.

40. Etter JF. Cytisine for smoking cessation: a literature review and a meta-analysis. Arch Intern Med 2006; 166: 1553-1559.

41. Rigotti NA. Cytisine-a tobacco treatment hiding in plain sight. N Engl J Med 2014; 371: 2429-2430.

42. Paskov D, Dobrev K. Pharmacological studies on citysine isolation in Bulgaria from Cytisus laburnum. Izv Na Meditsinskite Instituti Bull Inst Med Bulg Akad Na Nauk Sofia Otd Za Biol Meditsinski Nauki 1953; 8: 17-28.

43. Stoyanov S, Yanachkova M. Treatment of nicotinism with the Bulgarian drug Tabex. Chimpharm 1965; 2: 13.

44. Stoyanov S, Yanachkova M. Tabex-therapeutic efficacy and tolerance. Savr Med 1972; 23: 6

45. Dobreva D, Danchev N, Nikolova I. Tabex-Sopharma-natural alternative for smoking cessation and treatment of nicotine dependence. Pharmacia 2005; 52: 30-35.

46. Tabex. Product Monograph. Sopharma, Sofia 2006.

47. Tzankova V, Danchev N. Cytisine-from ethomedical use to the development as a natural alternative for smoking cessation. Biotechnol Biotechnol Equip 2007; 21: 151-160.

48. Seeger R. Cytisine as an aid for smoking cessation. Med Monatsschr Pharm 1992; 15: 20-21.

49. Paun D, Franze J. Tabex, registering and treatment of smokers with chronic bronchitis in the consultation against tobacco smoking. Medicobiol Inf 1970; 3: 14-19.

50. Castaldelli-Maia JM, Martins SS, Walker N. The effectiveness of cytisine versus nicotine replacement treatment for smoking cessation in the Russian Federation. Int J Drug Policy 2018; 58: 121-125.

51. Vinnikov D, Brimkulov N, Burjubaeva A. A double-blind, randomised, placebo-controlled trial of cytisine for smoking cessation in medium-dependent workers. J Smok Cessat 2008; 3: 57-62.

52. Korsak A. Dziś przestaję palić [Today i stop smoking]. Państwowy Zakład Wydawnictw Lekarskich, Warszawa 1983.

53. Zatoński W, Zatoński M. Cytisine versus nicotine for smoking cessation. NEJM 2015; 372 (11): 1072.

54. Starks T. Smoking under the Tsars A History of Tobacco in Imperial Russia. Social History of Medicine 2020; 33 (1): 335-336

55. Igari M, Alexander JC, Ji Y, et al. Varenicline and cytisine diminish the dysphoric-like state associated with spontaneous nicotine withdrawal in rats. Neuropsychopharmacology 2014; 39: 455-465.

56. Marks MJ, Grady SR, Salminen O, et al. $\alpha 6 \beta 2^{*}$-subtype nicotinic acetylcholine receptors are more sensitive than $\alpha 4 \beta 2^{*}$-subtype receptors to regulation by chronic nicotine administration. J Neurochem 2014; 130: 185-198.
57. Jeong SH, Newcombe D, Sheridan J, Tingle M. Pharmacokinetics of cytisine, an $\alpha 4 \beta 2$ nicotinic receptor partial agonist, in healthy smokers following a single dose. Drug Test Anal 2015; 7: 475-482.

58. Maliszewski L, Strączyński A. W sprawie stosowania preparatu „Tabex” [On the use of „Tabex”]. Wiadomości Lekarskie 1972; 25 (24): 2207-2210.

59. Granatowicz J. Smoking cessation through the use of cytisine and other chemotherapy. World Smoking Health 1976: 8-11.

60. Zatoński W, Cedzyńska M, Karpińska E. Raport: Ocena skuteczności i bezpieczeństwa stosowania roślinnego preparatu Tabex opartego o substancję czynną cytyzynę w leczeniu zespołu uzależnienia od tytoniu [Report: Evaluation of the efficacy and safety of the herbal Tabex preparation based on the active substance cytisine in the treatment of tobacco dependence syndrome] (F.17 - X M.K.CH) (ZUT). Otwarta obserwacja kliniczna 12-tygodniowa, przedłużona do 12 miesięcy (listopad 2003 - grudzień 2005) Medycyna Praktyczna, Kraków 2005.

61. Zatoński W, Cedzyńska M, Tutka P, West R. An uncontrolled trial of cytisine (Tabex) for smoking cessation. Tob Control 2006; 15: 481-484.

62. West R, Zatoński W, Cedzyńska M, et al. Placebo-controlled trial of cytisine for smoking cessation. N Engl J Med 2011; 365 (13): 1193-1200.

63. Blanke DD, de Costa e Silva V. Tools for advancing tobacco control in the 21st century. Tobacco Control Legislation: An introductory guide. World Health Organization, Geneva 2004.

64. Fagerström KO, Boyle P, Kunze M, Zatoński W. The anti-smoking climate in EU countries and Poland. Lung Cancer 2001; 32 (1): 1-5.

65. Zatoński W. Jak rzucić palenie. Profesor Witold Zatoński radzi [How to quit smoking. Professor Witold Zatoński advises]. Medycyna Praktyczna, Kraków 2007.

66. Roemer R. A brief history of legislation to control the tobacco epidemic. In: Tobacco and public health: science and policy. Boyle P (ed.). Oxford University Press 2004; 677-694.

67. Pertschuk M. Lesson in tobacco control advocacy leadership. In: Tobacco and public health: science and policy. Boyle P (ed.). Oxford University Press 2004; 669-676.

68. Walker N, Howe C, Glover M, et al. Cytisine versus nicotine for smoking cessation. N Engl J Med 2014; 371 (25): 2353-2362.

69. Walker N, Smith B, Barnes J, et al. Cytisine versus varenicline for smoking cessation for Māori (the indigenous people of New Zealand) and their extended family: protocol for a randomized non-inferiority trial. Addiction 2019; 114: 344-352.

70. Achieve Announces Successful Results from the Investigator-Initiated RAUORA. Available from: https://achievelifesciences. com/2020/06/29/achieve-announces-successful-results-from-investigator-initiated-rauora-trial/ (accessed: 10 October 2020).

\section{AUTHORS' CONTRIBUTION}

WAZ, KJK and AH prepared the first draft of the manuscript. All authors participated in preparing the final version of the article. 